\title{
Circling Back through Books
}

\author{
Kelly Pei Xuan Chia, Simon Fraser University
}

When I think about my experiences with reading, the real question I'm asking is when I started reading in English. That's when I started reading independently. That story starts from when I was three, in Malaysia, where I started trying to switch the voice in my head to English instead of my native dialect, Hakka Chinese. I would only talk to my dolls in English and read in it, too. Eventually, my thoughts were in English, and it became much more natural for me to think and read in English than in Chinese. My parents weren't very fluent in English themselves or were busy working, and my brothers did not want to read to me. So for the most part I taught myself how to read through television and library books, and I loved it.

The library was my favourite place as a five-year-old. I'd stock up on fantasy books about princesses, or books about how to take care of rabbits. I was determined to either be a princess or have a pet, since I couldn't do either of those things in our small apartment in Singapore. In fact, I could go anywhere in a book. I read about countries and landmarks I dreamed to visit, about the cute arctic hares and foxes I wished I could be friends with.

Reading in English felt like a safe way for me to explore the world, and it was an experience that I could confidently have by myself. At this age, I could read independently in English, but not in Chinese. When I read in Chinese, I felt like I had to ask for help with every character. In fact, I did so poorly in Chinese at school that I was often scolded or caned by my teachers. I didn't get good grades in Math either. English was the only subject I excelled in, and I was given cute pencil cases and notebooks by my teacher for doing well, so I found myself more motivated to read than practice any other subject.

But another strange thing happened as I read stories in English. Maybe it was just a subconscious effect of being ashamed about how bad I was at Chinese and only seeing white characters as main characters, but I started mimicking the characteristics of the people I read about. I think I wanted to be anyone but a Chinese second grader. When I wrote diary entries, I tried to sound like the kind

ENGL487W - Summer 2021 
fairies that I read about in the Rainbow Fairies books. I started practicing balancing books on my head like the princesses I read about. I wanted to be just like beautiful love interests I read about, with high cheekbones, lovely golden locks, and fair skin.

At that time, I never thought about why no one looked like me in the books I read: I questioned why I didn't look and sound like them. When I migrated to Canada in fifth grade, it got a little better and a little worse. Since I had read so many stories of the new kid in class being bullied, I was worried that I would be bullied, too. Plus, I really missed my home country - I'd beg my parents each day to reconsider moving back. I continued to do well in English, though I'd occasionally get micro-aggressive comments, like how people had never heard an Asian girl speak English without an accent. I started to get attached to graphic novels since I found that I could go through them really quickly, which was important since I continued to bring home mountains of books, and I loved the illustrations.

I read a lot of Pokemon manga, which is how I introduced myself to my now best friend of over eleven years: she was the first girl I met that also liked Pokemon! We would write stories based in the world of Pokemon by email, where we'd exchange writing chapters. It felt good to be these cute, powerful, adventurous main characters, since we largely kept to ourselves in school. This one time we had an argument, so I almost wrote my character out of the story, but her character apologized to me first in a chapter she wrote. These days, we still connect with the stories we like by writing about it. Meeting her was the first time the stories that I read helped me connect me with other people. I treasured my little reading world, but I happily learned that I could invite others into it.

It's also at this point that I would pick up a story nonchalantly in the library that would become far dearer to me than I could imagine: Sailor Moon. I remember looking at the manga in the library thinking that I'd try reading it because my mom loved it. I don't know what I expected, but I was at the age where I thought anything too girly was lame. Sailor Moon was the first queer book where I saw positive representation of genuine friendship and love between women, and the first time I learned about nonbinary people. I remember having a crush on one of the sailor scouts, Sailor Uranus, though I didn't really explore that at the time. I'd later find out that I was bisexual, and seeing queer relationships depicted as tender rather than a punchline helped me accept that. 
I admired the main character, Usagi Tsukino, who, against all odds and evils, chose to be kind. She sometimes had bad grades, but she was still a good person. I was a child who conflated doing well academically with morality. It meant so much to me to have her in my life, to model love and kindness for me. I would read the manga or watch the show when I was lonely or sick, and it would always cheer me up. It's safe to say now that I take a bit of her wherever I go.

Even if I considered Sailor Moon as a good model that was proud of her femininity, I was still skeptical of books that were too girly at the age of eleven. The saga that I grew attached to was The Hunger Games. I thought the story of Katniss Everdeen, this brave teenager who against all odds survived a game systematically rigged against her, was so fascinating. I watched her grow from a child who had to raise her sister to a revolutionary hero, and I admired how many burdens she had to carry. It's really the first novel I remember being so absorbed in, and I borrowed the sequels as soon as I finished the first one. I remember being completely frustrated that the movie adaptation removed her point-of-view and details like the Avoxes, who revealed how deeply corrupted the Capitol was, focusing instead on the love triangle between Katniss, Peeta, and Gale. It wasn't girly, which here meant shallow. It wasn't a documentary! I felt like I at least had a better understanding of the story than the movie directors, who in hindsight, were probably capitalizing from what they thought would appeal to young girls. I indignantly thought that this story was about a girl who grew up too early to be a martyr of a revolution, a role that she was forced into. This was the type of girl to idolize, not a girl in a girly love triangle!

I wouldn't have a chance to ask myself why girly was bad for a while, but I knew that anything that focused too much on romance was too simple for the stories about women I had learned to crave. There were books I feared reading because of what it'd say about my femininity, such as Twilight. The women I admired had to be tough and emotionless, not peppy, because peppy was bad. I didn't allow myself a lot of emotional development in the books and protagonists I chose, not until high school. Perhaps I did not want to be represented as the type of girl that media tends to depict as shallow: the peppy girl that adored romance. I didn't think my characters could be peppy, romantic, and deeply human and vulnerable.

I certainly had not asked why there weren't more characters that weren't white: the struggles of each character I read about would be filtered through class and mental health, not race. It was not until grade 11 when my AP English

ENGL487W - Summer 2021 
teacher assigned me Green Grass, Running Water that I was forced to confront how colonial my reading was. While we had been taught about residential schools, I'm ashamed to admit that it felt like every other Social Studies unit: in the past, with no consequences to the people in the present.

This book was unlike any other narrative I had read. It wasn't chronological, but it was cohesive, and it was the first time I understood that Indigenous peoples struggle presently with adapting to Western power structures. In that story, I read about women who oversaw the creation story: the narrative compared it against the Christian myth, and it blew my mind. This teacher gave us the space to talk about the ways our heavily Westernized literature obscured the voices and storytelling of other cultures. I will be forever grateful for it.

Now as an English major in university, I find myself especially interested in marginal voices being represented in fiction and nonfiction pieces. For me, my studies feel like solving a really satisfying puzzle about the reader, the author's culture, and the stories they've made. But as I nosedived into these texts, I also found myself reckoning with my lifelong relationship as a reader, academically and culturally, away from my Chinese heritage. I wrote about this disconnect in a school article and was heartened to find many other first-generation immigrants shared similar feelings about their culture: people that would forever feel a bit lost at the family dinner, and were rediscovering their culture with excitement, not shame.

As a reader, I've realized how much of my reading is through a Westernized lens, and how much time I've spent hiding from my culture as I study. While I am grateful for the pathways this has opened for me, I am trying to decolonize my reading by finding works that help me learn more about my culture. These days, I chase after books that I think make me feel that exclusive safeness that I felt when I was a child. Sometimes I find a book that touches me in more ways that I can explain, where I have to write about it in the margins of my notes after digesting it for days. For me, these books were Tuesdays with Morrie and Song of Achilles. I remember thinking about death, about life, and the relationships we make with other people. That's the best thing any work of literature can do for me: making me remember first and foremost how blessed I am to share my time with the people I love.

I work at a library now and I see so many more books featuring characters that look like me and my friends. Recently I read Jade City, an Asian-inspired 
fantasy story written by Fonda Lee, that didn't rely on age-old fetishistic

stereotypes in a book club with my friends. I loved that the world was so full, and that the characters felt so human when it hurt. It makes me wonder how many other books I can read that are lovingly embedded in the author's culture, too. I'd love some recommendations!

\footnotetext{
(c) (i) $\ominus$ This work is licensed under a Creative Commons AttributionEY NG ND NonCommercial-NoDerivatives 4.0 International License.
}

(C) Kelly Pei Xuan Chia, 2021 